\title{
Liberalismo radical e anarquismo no México porfirista
}

Felipe Deveza $^{\mathbf{1}}$

Resumo: A história das ideias radicais na América Latina, em particular daquelas que estavam associadas à classe operária, como o anarquismo e o socialismo, foi muitas vezes percebida a partir do prisma europeu, com pouco apreço pelas particularidades do continente. Este artigo analisa a recepção das correntes do anarquismo no México porfirista e ao longo da revolução mexicana com um foco nas ideias de Ricardo Flores Magón e no zapatismo do Estado de Morelos, explorando ressignificações e continuidades nas tradições políticas liberais mexicanas.

Palavras-chave: magonismo; zapatismo; Revolução Mexicana.

\section{Radical Liberalism and Anarquism in Porfirist Mexico}

\begin{abstract}
The history of radical ideas in Latin America, in particular those associated with the working class, such as anarchism and socialism, were often perceived in a European perspective, with limited appreciation for the particularities of the continent. This article analyzes the reception of the currents of the anarchism in Porfirist Mexico throughout the Mexican revolution focusing on the ideas of Ricardo Flores Magón and the zapatism of the State of Morelos, exploring resignifications and continuities in the liberal Mexican political traditions.
\end{abstract}

Keywords: magonism; zapatismo; Mexican Revolution.

\section{Artigo recebido em: 03/01/2020}

Artigo aprovado para publicação em: 17/04/2020

Mesmo entre os pesquisadores latino-americanos, por diversas vezes a história da região foi encarada como reprodução, ou condicionada por etapas e conceitos políticos originados na história europeia. Embora alguns autores importantes tenham feito esforços por demonstrar as particularidades na história latino-americana, o espelhismo se mantem como uma sombra. A história das ideias radicais, em particular daquelas que estavam associadas à classe operária, como o anarquismo e o socialismo,

\footnotetext{
1 Doutor em História Comparada pela Universidade Federal do Rio de Janeiro, pós-doutorando no Programa de Pós-Graduação em História da Universidade Federal Fluminense, com pesquisa intitulada “O Movimento Muralista Mexicano e a política no México Pós-Revolucionário". E-mail de contato: felipedeveza@gmail.com.
} 
foi muitas vezes percebida a partir do prisma europeu, com pouco apreço pelas particularidades latino-americanas.

Nas décadas de 1960 e 1970, um grupo de pesquisadores marxistas argentinos passou a editar uma revista de crítica marxista denominada Pasado y Presente. Essa publicação, com vida curta e poucos números, foi muito influente entre a esquerda latino-americana e renovou significativamente o olhar sobre o marxismo na América Latina. A partir dessa revista, desenvolveu-se uma série de publicações agrupadas na coleção Cuadernos del Pasado y Presente, que até os dias atuais são a mais importante compilação de documentos, coleções de textos e análises acerca de Marx, do marxismo e da história do marxismo na América Latina em língua espanhola.

À frente dessa publicação e como principal animador desse grupo de intelectuais e ativistas, esteve José de Aricó (1931-1991)². Outros nomes importantes do grupo foram Juan Carlos Portantiero, Oscar del Barco, Hector Schmucler, entre outros.

Os cadernos trouxeram muitos elementos para o aprofundamento do debate marxista na América Latina, particularmente a coletânea de trechos da obra de Marx e Engels sobre a América Latina. E Aricó estava preocupado em responder uma questão importante para as particularidades latino-americanas.

\footnotetext{
Se socialismo e movimento operário são ainda hoje na Europa dois aspectos de uma mesma realidade - por mais contraditórias e nacionalmente diferenciadas que se evidenciem suas relações - na América Latina constituem duas histórias paralelas que em contadas ocasiões se identificaram e que na maioria dos casos se mantiveram separadas e até opostas entre si. (ARICÓ, 1999, p. 23).
}

Para Aricó era importante explicar essa dificuldade do marxismo na América Latina. Responder essa questão estava diretamente relacionado à estratégia que os marxistas deveriam empregar no continente.

Nos últimos anos de vida de Engels, os socialistas começaram a conquistar cadeiras no parlamento dos Estados europeus, principalmente na Alemanha. A dura

\footnotetext{
${ }^{2}$ Uma boa apresentação da Obra de Aricó, ver: CRESPO, Horacio, "Presentación", In: ARICÓ, José María, Entrevistas, 1974-1991, Córdoba: Universidad Nacional de Córdoba, 1999.
} 
repressão que viveram logo após 1848 e depois de 1871 foi se transformando e pareceu para muitos líderes socialistas que o caminho para a sociedade sem classes seguiria sem violência, de maneira progressiva como consequência de um processo de desenvolvimento civilizatório em direção ao comunismo. Somente depois da Primeira Guerra Mundial que esse estado de espírito mudaria radicalmente. Nos últimos anos do século XIX, a ascensão do movimento socialista e uma forte influência do liberalismo positivista estimulavam e alimentavam essa perspectiva.

Diferente da Europa, na América Latina a classe operária nascia em um ambiente de quase inexistente representação popular no parlamento, com liberais na oposição e uma hegemonia da oligarquia conservadora no Estado. Diversos episódios nos quais os liberais reivindicavam simples reformas democráticas foram reprimidos com violência pelas forças do Estado. Em uma população com altos índices de analfabetismo, de população fragmentada por um grande território em algumas dezenas de cidades, o marxismo da $2^{\text {a }}$ Internacional $^{3}$, progressivista, pacifista e parlamentar, tinha dificuldades em conquistar adeptos. Nas palavras de Aricó:

\begin{abstract}
A segunda consequência se refere às expressões ideológicas de todo esse processo. Porque é evidente que as dificuldades objetivas com que a classe operária enfrentava para constituir-se como tal se davam no interior de um tecido nacional e continental em que predominavam uma multiplicidade de correntes democráticas revestidas de um forte caráter social, duradouras esperanças messiânicas em uma regeneração universal, sem que existissem entre elas as fronteiras mais ou menos precisas que a Revolução de 1848 foi estabelecendo na Europa [...] Nesse mundo de violência e messianismo, de mitos e milenarismos que marcaram a luta das classes subalternas contra a desagregação social e a opressão capitalista, o socialismo moderno proposto pela doutrina de Marx encontrava obstáculos muito difíceis de evitar para a sua difusão. (ARICÓ, 1999, p. 30).
\end{abstract}

\footnotetext{
${ }^{3}$ É importante assinalar que a Segunda Internacional assume uma posição cada vez mais progressivista nos últimos anos do século XIX, e principalmente na primeira década do século XX. Para acompanhar os debates na Segunda Internacional, ver: LA SEGUNDA INTERNACIONAL y el Problema Colonial (primera parte) Caderno 73, México: PYP, 1978 e LA SEGUNDA INTERNACIONAL y el Problema Colonial (segunda Parte) Caderno 74, México: PYP, 1978.
} 
Nesse contexto, foi o anarquismo que encontrou espaço, primeiramente entre a intelectualidade liberal marginalizada, e, posteriormente, entre os operários, muitos deles estrangeiros.

Foram as correntes anarquistas as que, pelo menos até os anos 20 do presente século $[\mathrm{XX}]$, mostram extrema ductilidade para representar boa parte de todo este hibrido mundo de pensamentos inspirados em projetos de reformas sociais e de justiça econômica, mantendo, contudo, uma estreita vinculação com as classes operárias urbanas. (ARICÓ, 1999, p. 33).

Para Aricó, a impossibilidade de se participar do jogo político institucional, a repressão e o controle político conservador propiciavam um ambiente de desespero político, em que a única opção seria uma ruptura total com o Regime Oligárquico, um tipo de resolução catastrófica que combinaria com muitas visões milenaristas que se desenvolveram entre as comunidades serranas do altiplano andino e entre as comunidades camponesas que tinham suas terras usurpadas pela expansão das monoculturas.

\footnotetext{
A reação imediata contra a "desordem social" imposta pelas classes dominantes encontrava nas doutrinas libertárias uma ideologia acorde com uma visão que se fundava na eliminação física de toda a estrutura autoritária e repressiva a possibilidade de liberação dos homens. As esperanças postas em uma resolução catastrófica e imediata do presente, que é típica do mundo de nosso século e particularmente de suas zonas periféricas, tornava definitiva e prescindível toda a estratégia que se colocara objetivos futuros em longo prazo. (ARICÓ, 1999, p. 33).
}

$\mathrm{Na}$ América Latina foi do liberalismo radical, de alguns setores das classes médias, como jornalistas, que derivou a difusão das obras de agitação que circulavam no meio operário europeu. Nas condições restritivas de participação popular, prevaleceu o anarquismo, muito eclético, mas de viés sindicalista, como inspiração para os primeiros organizadores do movimento operário em uma perspectiva autônoma. 


\title{
A radicalização liberal no México.
}

O caso mexicano é exemplar desse processo de radicalização de partes das classes médias excluídas de participação política, que passavam do liberalismo radical ao anarquismo. Exemplo similar, embora em uma escala muito menor, aconteceu no Peru, com Gonzáles Prada e seus partidários da Unión Nacional.

Arnaldo Córdova (1991), ao tratar do anarquismo de Ricardo Flores Magón, que surge do interior do movimento liberal, em oposição ao governo de Porfírio Diaz, pontua a relação entre o liberalismo radicalizado e o anarquismo em uma nota de seu livro.

\begin{abstract}
O anarquismo é sem dúvida uma etapa, a mais radical no processo de desenvolvimento lógico do liberalismo, tanto política como economicamente. Em ambas as doutrinas é preocupação fundamental a atividade reservada ao Estado dentro da sociedade, dessa maneira, da restrição do poder estatal dos liberais, os anarquistas passam à abolição de todo Estado, sem estabelecer nenhuma diferença, nem sequer de matiz, entre as formas que este pode adotar, ou a serviço de que classe ou grupo a adota. Da fórmula clássica de que o melhor governo é o que governa menos, o anarquismo sem gradação alguma conclui que o melhor governo é o que não existe; a dicotomia autoridade-liberdade é para ele absoluta. (BLANQUEL apud CORDOVA, 1991, p. 175).
\end{abstract}

Essa relação de hereditariedade entre o radicalismo anarquista e o liberalismo latino-americano possibilitou aos anarquistas mexicanos uma posição muito vantajosa no debate acerca da realidade em que estavam inseridos. Superaram uma tendência ao isolamento que o radicalismo de origem bakuninista ${ }^{4}$ poderia impor em uma sociedade agrária, com uma ínfima e recente classe operária, em que as relações pessoais regulavam a organização do trabalho.

Foi por essa origem no liberalismo que os anarquistas mexicanos procuraram se organizar em partido, além de terem sido flexíveis quanto a diversas formas de

\footnotetext{
4 A expressão Bakuninista refere-se às ideias defendidas por Mikhail Bakunin e seus seguidores na Associação Internacional dos Trabalhadores. Em uma coletânea de textos produzidos na AIT, Marcelo Musto denomina os seguidores de Bakunin como autonomistas. Ver: MUSTO, Marcello. Trabalhadores Uni-vos! Antologia Política da I Internacional, São Paulo: Boitempo, 2014.
} 
participação política. É também por essa dupla filiação que foram os anarquistas que agitaram as mais latentes questões da sociedade, invisíveis para a maioria dos liberais. Por outro lado, mesmo inspirados pelo anarco-sindicalismo europeu, ultrapassaram o âmbito da fábrica urbana e iniciaram reflexões importantes sobre as questões étnicas, nacionais e principalmente agrárias.

\section{Ricardo Flores Magón e La Regeneración}

Para criar novas perspectivas em uma realidade de opressão e miséria, os revolucionários olham para o passado, o idealizam como alternativa para transformar e criar algo novo. Assim, no México porfirista, as ideologias da Revolução nasceram acompanhadas da defesa do passado liberal. ${ }^{5}$

Desde o início, o passado não era o porfirismo, senão a tradição libertária que se deu a partir da Revolução de Independência, se desenvolve em um longo período de luta dos liberais contra os conservadores e culmina com o triunfo da República nas guerras da Reforma e contra a intervenção francesa. (CORDOVA, 1991, p. 87).

Com um incipiente proletariado e com revoltas camponesas de caráter local e sem perspectivas nacionais, coube aos intelectuais médios da cidade a organização de um movimento de oposição. Os fundamentos dessa oposição seriam encontrados no

\footnotetext{
${ }^{5}$ La revolución que comenzó Madero, y que arreció tras su asesinato, no partió de cero: tuvo como base el liberalismo - en su versión mexicana, juarista - La tradición liberal que partía de la Constitución de 1857, ofrecía un programa que comprendía la defensa de las garantías individuales, de las libertades políticas, de la correcta aplicación de la ley y de la justicia, así como el ideal de una sociedad democrática. Había también valores compartidos por sectores e individuos de todas las clases: la importancia de la educación y del trabajo, de la honestidad. Muchos liberales buscaban también limitar lo que consideraban la perniciosa influencia de la Iglesia, así como el alcoholismo. A ese sustrato ideológico se agregaron las demandas de los campesinos e indígenas, las de los obreros y artesanos, las de las clases medias, en una amalgama que mezclaba un liberalismo popular con ideas agraristas, nacionalistas, mutualistas, del catolicismo social de las que se desprendieron las propuestas de las diversas facciones revolucionarias en los diez años que siguieron al llamado de Madero. (ÁvILA e SALMERÓN, 2017)
} 
antigo liberalismo juarista ${ }^{6}$, em que era possível encontrar a inspiração de democracia política que almejavam ${ }^{7}$.

A faísca que incendiaria os meios liberais da época porfirista seria o discurso do bispo de San Luis Potosi, em junho de 1900. Proclamado na Assembleia Geral do Congresso Nacional de Agências Católicas, o bispo afirmou que no México a Igreja havia progredido apesar das restrições impostas pelas Leis da Reforma, denunciava a separação entre a Igreja e o Estado e que, sob o benévolo governo de Diaz e o apoio das mulheres mexicanas, as Leis da Reforma não passavam de letra morta. (COCKCROFT, 1981, p.90; CORDOVA, 1991, p. 90).

O discurso do bispo Montes de Oca y Obregón (1840-1921) fez com que Camilo Arraiga (1862-1945), apoiado por outros liberais de San Luis de Potosi, publicasse um manifesto convidando os clubes liberais a se reunirem em uma Convenção Nacional em San Luis de Potosi, em fevereiro de 1901. (COCKCROFT, 1981, p. 90).

Camilo Arraiga era um engenheiro de minas, membro de uma das famílias mais abastadas da região, que havia passado um período pela Europa, de onde havia trazido muitos livros. De sua biblioteca particular liam-se muitos dos autores radicais, principalmente anarquistas, que influenciariam todo o grupo de liberais reunidos no entorno de Camilo ${ }^{8}$.

\footnotetext{
${ }^{6}$ Benito Juárez promungou uma série de leis de cunho liberal em meados do século XIX, como a Lei do Matrimônio Civil, a que nacionalizava os bens eclesiásticos ou o decreto de secularização dos cemitérios. $\mathrm{Na}$ História independente do México, as diferenças entre liberais e conservadores estiveram muitas vezes relacionadas à luta contra os privilégios da Igreja e na defesa do Estado laico.

${ }^{7}$ Cockcroft nos conta que: "[...] [Félix Palacini] cria que a próxima revolução social do México se iniciaria com os 'intelectuais da classe média' e com o 'proletariado intelectual' [...] cria que os intelectuais do México haviam sido a principal força dinâmica de toda a história da República desde a Guerra da Independência [...] advertia: 'a classe média intelectual', quando se enfrente com a 'fome chamando às portas', com os salários reduzidos, com a carência de vestido, com o indecente alojamento, com o pão caro e a carne 'ruim e cara', 'será revolucionária': 'O proletariado intelectual iniciará sua defesa'”. (COCKCROFT, 1981, p. 46).

8 "Santiago de la Veja declarou mais tarde: 'Graças a Camilo - Camilito, como o chamávamos - toda a biblioteca Stock de Paris fez parte de nossas bagagens de prisioneiros' A Biblioteca Stock foi uma proeminente casa de publicações e livrarias em Paris da qual através de sua Biblioteca Anarchiste distribuía as obras dos líderes anarquistas europeus, e a través de sua Bibliothèque cosmopolite" oferecia as obras de autores mundialmente conhecidos (Tolstoi, Ibsen, Hugo, Kipling e outros.)". (COCKCROFT, 1981, p. 69.)
} 
No manifesto de Arraiga estava definido que se discutiria e se necessitaria decidir os meios "de levar a prática a unificação, a solidariedade e força do Partido Liberal, a fim de conter os avanços do clericalismo e conseguir dentro da ordem e da lei a vigência efetiva das Leis da Reforma”. (Ibidem, p. 69) 9 .

A reunião liberal ocorreu em fevereiro de 1900 e contou com muito mais delegados do que estavam esperando inicialmente. Entre os delegados, estava o jovem Ricardo Flores Magón (1874-1922), que do seu jornal Regeneración ${ }^{10}$ passou à oposição ativa ao governo com denúncias e um crescente radicalismo. Inicialmente, o objetivo do jornal era essencialmente legalista: combater e denunciar as falhas da justiça, os juízes venais, os litigantes imorais e as autoridades arbitrárias (CÓRDOVA, 1991, p. 91).

Regeneración noticiaria no número $26^{11}$ detalhes do Congresso, e reconheceria a liderança de Arraiga sob o movimento liberal mexicano. A transformação de um liberalismo legalista, crente nas possibilidades de conquistar reformas políticas pelo Estado, vai desenvolvendo-se e radicalizando o discurso. Esse processo é facilmente acompanhado pelas páginas de Regeneración. Em 1900, pouco antes da Convenção (ou Congresso) Nacional do movimento liberal, o periódico, antes dedicado às questões jurídicas, avança para o tratamento de questões mais amplas. A partir do número $20^{12}, \mathrm{o}$ jornal dos irmãos Flores Magón passou a denominar-se Regeneración, Periódico Independiente de Combate e apresentou suas proposições:

\begin{abstract}
A justiça, mal administrada como tem estado até esta data, foi o que primeiro nos induziu a fundar nosso periódico [...] Nossa luta tem sido dura. Tem tido todas as características de uma luta de pigmeus encarando titãs [...] Nossa luta por Justiça, não era mais que um reflexo de nossos princípios; mas essa luta se via circuscrita a um mesquinho raio de ação: não podíamos tratar mais que de assuntos jurídicos. [...] Por outra parte, continuaremos tratando os assuntos jurídicos, como até esta data, e seguiremos fazendo as críticas, quiçá um tanto amargas, mas nem por isso menos justas, dos atos dos empregados judiciais. (REGENERACIÓN, n. 20, 31 de dez. 1900).
\end{abstract}

\footnotetext{
${ }^{9}$ Ibidem, p. 78.

${ }^{10}$ O Jornal Regeneracion está disponível digitalmente em: http://archivomagon.net/periodicos/.

${ }^{11}$ REGENERACIÓN, El Gran Congreso Liberal. Regeneración, México, DF, n. 27, 15 fev. 1901.

${ }^{12}$ Idem. Periódico independiente de combate. Regeneración, México, DF, n. 20, 31 dez. 1900.
} 
As críticas amargas vieram cada vez mais dirigidas a Porfírio Diaz. No número 34, dizia: "Não acredite que nos dirigimos a esta personalidade para adular [...] Nos dirigimos ao presidente para por em manifesto o grave mal que tem ocasionado com seu sistema político, ditatorial, absorvente, absoluto, autocrático" (REGENERACIÓN, n. 34, 15 abr. 1901, p. 1$)^{13}$.

Frente ao sucesso do Congresso e ao crescimento da oposição liberal, Enrique e Ricardo Flores Magón são presos, logo depois seria encarcerado também Antonio Diaz Soto y Gama (1880-1967), outro importante participante do chamado grupo precursor da Revolução Mexicana.

A ideologia de oposição ao Governo Diaz nasceu liberal e foi transformando-se ao longo dos conflitos. Fechada qualquer via de transição política, a radicalidade crescente de Regeneración foi conquistando leitores. O jornal havia sido fundado pelos irmãos Jesus e Ricardo Flores Magón, e depois se incorporaria o irmão mais novo, Enrique. O destaque seria para Ricardo, mas, além dos irmãos, no círculo do jornal teriam importância também Práxedes Guerrero (1882-1910), Librado Rivera (1864-1932), Antonio I. Villarreal (1879-1944) e Juan Sarabia (1882-1920).

Com Ricardo ainda preso e a fim de ampliar o movimento liberal, Arraiga e José Maria Facha convocam o $2^{\mathrm{a}}$ Congresso do Partido Liberal Mexicano, em que se especificam os temas a serem debatidos, entre outros a liberdade de imprensa e a resolução do problema agrário.

Os liberais em processo de definição programática esbarravam na questão que assolava os também 3/4 da população mexicana, o problema agrário. ${ }^{14}$.

Sem condições de fazer oposição de forma legal, Ricardo Flores Magón se exila em San Antonio, no Texas, e do território norte-americano continua a publicar Regeneración. Em 1903, um agente de Porfírio Diaz tenta assassiná-lo, sem êxito.

\footnotetext{
${ }^{13}$ Idem. Al Presidente de la República, Regeneración, México, DF, n. 34, 15 abr. 1901.

${ }^{14}$ Como no Peru a questão indígena, embora evidente, mantinha-se sob desinteresse dos letrados da capital, no México a questão agrária somente havia sido tratada em favor do campesinato por Wistano Luis Orozco, com o livro: "Legislación y jurisprudência sobre terrenos baldios" ver: OROZCO, Wistano Luis. "Legislación y jurisprudência sobre terrenos baldios." Disponível em: http://biblio.juridicas.unam.mx/libros/2/940/40.pdf. Acesso em: 25 nov. 2019.
} 
A partir de 1905, forma-se uma Junta Organizadora do Partido Liberal Mexicano, com Ricardo à cabeça. Na situação de repressão política, fechados os caminhos institucionais, o tom legalista perdeu espaço nos clubes liberais, e os mais radicais, que permaneceram politicamente mais ativos, foram ganhando maior importância entre os que se opunham à ditadura de Diaz.

É nesse momento, por volta do ano de 1904, que o liberalismo radicalizado de Regeneración vai sendo suplantado pelo anarquismo, estabelecendo relações cada vez mais fortes com os operários. Entre os dias 1 e 3 de junho de 1906, foi deflagrada uma greve operária que se tornaria historicamente importante, em Cananea. Os organizadores dessa greve estavam reunidos na União Liberal Humanitária.

Os protestos por melhores salários e equiparação com os salários pagos aos norte-americanos foram reprimidos pela força particular da empresa de mineração com o auxílio de alguns mineiros de nacionalidade norte-americana. O dono da empresa solicitou a intervenção de tropas norte-americanas, que atravessaram a fronteira do México com o Arizona, e os mineiros foram atacados e reprimidos. Essa greve foi duramente reprimida pelo Governo e descrita em um artigo de Ricardo Flores Magón, assinado com o pseudônimo de Netzahualpilli, da seguinte maneira ${ }^{15}$ :

\begin{abstract}
Declarou-se a greve. Ninguém voltaria a entrar nas minas para trabalhar, já que as famílias dos trabalhadores eram colocadas na miséria para que se engordassem e gozassem a vida das famílias dos que não suavam. Seis mil homens deixaram cair a ferramenta, animado pela esperança de que, arrependidos, os amos atenderiam suas reclamações. Vã esperança. Os amos armaram seus lacaios e assassinaram o povo. O governo, por sua parte, mandou soldados que fizeram o mesmo e, covarde e traidor, tolerou que foragidos estrangeiros violassem as leis de neutralidade para exterminar aos mineiros mexicanos.

(...) Que espantoso crime os mineiros haviam cometido para serem caçados como bestas selvagens? Um crime realmente e muito grande, um monstruoso crime: o de reclamar seu direito com as mãos vazias. Esse é o crime dos povos submetidos e escravos.
\end{abstract}

\footnotetext{
${ }^{15}$ Netzahualpilli ou Nezahualpilli foi o tlatoani de Texcoco entre 1473 e 1515, conhecido por abolir a pena de morte para escravos e soldados em alguns crimes.
} 
(...) Os direitos não se reclamam cruzando os braços, senão com o ferro e com o fogo. Armem-se os operários e reclamem seus direitos, só assim se conquista a liberdade e o bem estar. (FLORES MAGÓN, 1908) ${ }^{16}$.

No final de 1906, trabalhadores de Rio Blanco reagiriam a um lockout ${ }^{17}$ nas indústrias têxteis, atacando e destruindo a fábrica. $\mathrm{O}$ governo não hesitaria em reprimir os operários. Alguns autores chegam a contar a morte de 800 pessoas nesse conflito. (BARBOSA, 2010, p. 55).

Um mês depois da Greve de Cananea, o PLM lançaria seu programa revolucionário, que definiria dois campos no liberalismo mexicano pré-revolução. Por um lado, uma tendência puramente liberal (CORDOVA, 1991, p. 96), que depois seria encarnada pela figura de Francisco Madero, e outro campo, agitado pela prédica anarquista de Ricardo Flores Magón, avançando do liberalismo radicalizado para um anarco-sindicalismo com características particulares, que receberia o nome de magonismo $^{18}$.

Melgar Bao explica os motivos que levaram o liberalismo mexicano ao encontro da parte mais radical do movimento anarquista:

A repressão constante contra os clubes liberais e seus órgãos de imprensa, foi acelerando o processo de radicalização ideológica e política destes setores até os fazer convergir com o movimento operário que se desenvolvia de maneira espontânea, autônoma e que igualmente era objeto de repressão governamental (MELGAR BAO, 1988, p. 179).

O próprio Ricardo Flores Magón explica a transição de seu pensamento e confirma a assertiva de Melgar Bao:

\footnotetext{
${ }^{16}$ NETZAHUALPILLI (Pseudônimo de Ricardo Flores Magón), Libertad y Trabajo, Los Angeles, 30 maio 1908. Disponível em: 〈http://www.fte-energia.org/E80/e80-17.html> e em Memoria, México, n 245, p. 39-40, ago. 2010.

17 Lockout é o termo utilizado para definir o ato dos donos de uma empresa para impedir que os funcionários exerçam suas funções. Como uma "greve" patronal. Essa tática é utilizada para impedir e dificultar negociações em meio a uma greve de trabalhadores, ou a ameaça de uma. Na maioria dos países, essa prática é proibida por lei.

${ }^{18}$ Denominamos como magonismo o conjunto de ideias que fizeram parte do pensamento de Ricardo e Enrique Flores Magón, bem como de seus companheiros do PLM na fase anarquista, como Práxedes Guerrero.
} 
O avanço das minhas ideias é lógico, não tem nada de estranho nele, nada de postiço. Primeiro acreditei na política. Eu acreditava que a lei teria a força necessária para que houvesse justiça e liberdade. Mas vi que em todos os países ocorria o mesmo que no México, que o povo do México não era o único desgraçado e busquei a causa da dor de todos os pobres da terra e a encontrei: o capital. (FLORES MAGÓN apud CORDOVA, 1991, p. 175).

O Programa do PLM é interessante por demonstrar algumas desconfianças de um anarquismo ainda incipiente, que depois seria mais pleno e claro. Em 1906, o PLM ainda recomendava receio frente ao governo, e não a negação de qualquer participação.

[...] é preferível impor aos liberais a obrigação de velar pelo cumprimento do programa, para que assim recorde continuamente que não deve fiar demasiado em nenhum governo, por exemplar que pareça, senão que devem vigiá-lo para que chegue a seus deveres. Esta é a única maneira de evitar tiranias no futuro e de assegurar que o povo goze e aumente os benefícios que conquiste. (PARTIDO LIBERAL MEXICANO, 1906, s.p.) ${ }^{19}$.

O programa, que depois Ricardo recordaria como muito ameno, declarava-se contra a reeleição e pela redução do mandato presidencial para 4 anos. Opunha-se ao serviço militar obrigatório e reivindicava liberdade de imprensa, igualdade jurídica para militares e civis, abolição da pena de morte (exceto por traição), expansão da educação pública laica, valorização do magistério, valorização dos mexicanos sobre os estrangeiros, proibição da imigração chinesa $^{20}$, limitação do poder do clero, melhoria das condições de trabalho, 8 horas de trabalho, salário mínimo, proibição do trabalho infantil, descanso dominical, reforma agrária, fortalecimento dos laços com os países latino-americanos, proteção da raça indígena, entre outros. (PARTIDO..., 1906, s.p.).

O grupo do PLM continuou organizando a resistência por meio da propaganda e da agitação política pelos jornais. Depois formariam grupos clandestinos pelo país, que

\footnotetext{
${ }^{19}$ PARTIDO Liberal Mexicano, Programa del Partido Liberal y Manifiesto a La Nación, St. Louis, $1^{\circ}$ jul. 1906. Disponível em: <http://www.antorcha.net/biblioteca_virtual/historia/programa/44.html>. Acesso em: 25 nov 2019.

${ }^{20}$ A proibição de imigração chinesa é um ponto do programa do PLM que depois se repetiria em outras organizações na década de 1920, e seria combatido intensamente pelos comunistas, e particularmente através da Liga Anti-imperialista, conforme veremos no capítulo 3 deste trabalho.
} 
animariam diversas mobilizações, como a Greve de Orizava, em Veracruz, uma guerrilha em 1908 em Yucatán, até que o PLM passasse à organização e defesa aberta da revolução social através da luta armada ${ }^{21}$.

(...) Em defesa da Justiça, ultrajada sem tréguas por um punhado de bandoleiros que nos oprimem, nos rebelamos contra a ditadura de Porfírio Diaz e não deporemos as armas que temos empunhado com toda justificativa, até que na união de todo o Partido Liberal Mexicano, tenha triunfado o programa promulgado no dia $1^{\circ}$ de julho do corrente ano, pela Junta Organizadora do Partido Liberal. (PARTIDO..., 1906) ${ }^{22}$.

Quando Madero lançou o Plano de San Luis de Potosí em 1910, e conclamou o povo mexicano às armas, os magonistas levantaram-se em várias partes do país, mas concentraram-se no território isolado da Baixa Califórnia, onde imaginavam conseguir resistir. ${ }^{23} \mathrm{O}$ magonismo maduro combinou radicalismo, levante camponês armado e coletivismo agrário, e argamassa para as mais radicais correntes do agrarismo mexicano, anos depois.

${ }^{21}$ Cockcroft (1981, p. 135) “[...] também nasceu uma revolução durante 1906-1908, tanto em termos ideológicos, como de preparação militar; o PLM aportou contribuições-chave ao desenvolvimento da Revolução de 1910-1917. Ainda que não tivessem alcançado êxito na derrubada de Porfírio Diaz, as revoltas do PLM ajudaram a sovacar seu regime. As ideias do Programa do PLM começam então a receber uma ênfase mais militante em benefício da classe operária”.

22 PARTIDO Liberal Mexicano, Proclama a la nación, St. Louis, set. 1906. Disponível em: <http://www.antorcha.net/biblioteca_virtual/historia/programa/45.html>. Acesso em: 27 mar 2014

${ }^{23}$ Ricardo Flores Magón noticia, em uma carta de 28 de junho de 1911, o andamento dos combates no norte do México. Emílio campa foi um dos que assinaram o Plano de Empacadora, conhecido como Plano Orozquista. O trecho abaixo demonstra a relação direta entre Ricardo e as forças revolucionárias, particularmente Pascual Orozco. "Por falta de parque se perdió Tijuana. Los bravos compañeros lucharon ahí como leones hasta que quemaron su último cartucho. [...] Agotado el parque, los compañeros se pasaron al lado americano. Mexicali se perdió por la traición de Rodolfo Gallegos, un miserable que nos engaño vilmente y se vendió a los capitalistas americanos del norte de la Baja California. Sin embargo, los pesimistas no deben desalentarse, pues sería ridículo pretender que la Revolución Social estaba confinada en un rincón del territorio mexicano. Acabo de recibir cartas muy interesantes de los Estados de Chihuahua y Coahuila. Una es del firme y valeroso compañero José María Rangel, quien con el no menos firme y valeroso Inés Salazar, hacen la campaña liberal en el norte de Chihuahua. [...] Me dice Rangel en carta del 20 de este mes, que estaba ya para unir a su columna otra columna liberal que anda por el rumbo de San Antonio, Chihuahua. Si ya se unieron, muy pronto será dueña la bandera roja de una gran extensión territorial del Estado de Chihuahua. [...] Como es muy difícil la comunicación, no tenemos detalles de más operaciones de dichos compañeros." Disponível em: <http://www.antorcha.net/biblioteca_virtual/politica/reflexiones/5.html>. Acesso em: 27 mar 2014. 
Oficialmente, a Revolução Mexicana começou com a convocação de Madero em novembro de 1910. Para conseguir apoio dos magonistas, chegaram a espalhar um boato de que Ricardo poderia ser o vice em uma futura presidência de Madero após a Revolução. A essa altura, Ricardo já estava plenamente convencido do anarquismo, e fez questão de responder, pelas páginas de Regeneración com um rotundo "não" e muita propaganda anarquista ao convite oficioso maderista.

Os magonistas se lançaram à luta e no norte de Chihuahua fizeram uma série de ataques contra as forças federais, conquistando posições e agrupando combatentes. Em uma dessas lutas, morreu Práxedes Guerrero, um dos mais importantes membros da direção do PLM em uma das frentes de batalha próximas à fronteira. Práxedes Guerrero foi um importante militante anarquista e seus artigos possuem muitas posições próximas ao que depois seria considerado como as bases do leninismo em termos de organização clandestina. Barbosa (2010, p. 57) chama a atenção para a proximidade do magonismo e a forma de organização do PLM, em células centralizadas e clandestinas, com o modelo de organização partidária leninista.

Entre os diversos grupos do PLM que lutaram na primeira fase da Revolução Mexicana, estiveram os magonistas, os quais em 1911 tomaram algumas cidades do território de Baixa Califórnia, que alguns afirmam ser o primeiro intento de fundação de um Estado socialista no século XX, seis anos antes dos bolcheviques tomarem o poder na Rússia.

O Governo Diaz manteve a repressão a qualquer dissidência política e com isso prejudicou os liberais mais moderados, que nesse contexto sucumbiam como alternativa frente aos radicais do PLM. Sem muitas opções, os liberais que representavam a oligarquia marginalizada no porfiriato se reuniram em torno da figura de Madero, que única e exclusivamente propunha uma transição política e não uma transformação revolucionária da sociedade. 
O tom conciliador do liberalismo que Madero representava ficou claro em seu livro Sucessión Presidencial ${ }^{24}$. Espírita kardecista, Madero imaginava-se realizando uma missão transcendental. A sua proposta de governo, expressa no Plano de San Luis de Potosi $^{25}$, além da reivindicação por democracia política, estava bem limitada em relação a uma proposta de transformação social.

Definidos os campos, Magón aprofundaria sua posição anarquista e se ligaria mais e mais aos operários e camponeses, ao mesmo tempo que se incompatibilizava com o maderismo.

As ideias de Magón, muito depressa, passaram a ser divulgadas, associandose a elas, segundo Angel Capelletti, o grito revolucionário de Tierra y Liberdad. O referido lema teria sido entoado primeiro pelo poeta e militante anarquista Práxedis Guerrero e depois disseminado pelos magonistas. Entretanto, foi Soto y Gama, um magonista muito próximo a Emiliano Zapata, que viria a popularizá-lo junto ao exército zapatista. (SAMIS, 2003, p.19) 26,27 .

Da visão bakuninista que associa o Estado ao Capital, o grupo de Regeneración evolui para a associação da propriedade do solo ao Capital (CORDOVA, 1991, p. 178). Na lógica do comunalismo kropotiano, Magón encontra a comunidade indígena, os Capullis e os Ejidos, que possibilitaram novos elementos radicais para a Revolução Agrária que seguiria pelos próximos anos.

O apoio mútuo era igualmente a regra; as casas se fabricavam em comum; a moeda quase não era necessária, porque havia intercâmbio de produtos, mas

\footnotetext{
24 MADERO, Francisco, Sucesión Presidencial, INEP AC, 1910. Disponível em: <http://www.memoriapoliticademexico.org/Textos/6Revolucion/1910LSP.pdf>. Acesso em: 27 mar 2014 ${ }^{25}$ O Plano de San Luis Potosi pode ser encontrado em: GARCIADIEGO, Javier. Textos de la revolución Mexicana, Caracas: Biblioteca Ayacucho, 2010, p.190.

${ }^{26}$ SAMIS, Alexandre. Apresentação. In: FLORES MAGÓN, Ricardo. A Revolução Mexicana. São Paulo: IEL - Imaginário, 2003.

${ }^{27}$ Embora Samis (2003, p.19) afirme que o lema Tierra y Libertad tenha sido popular entre os zapatistas, a verdade é que essa consigna nunca fez parte de nenhum documento zapatista, que assinavam normalmente: Reforma, Libertad, Justicia y Ley (um exemplo: o comunicado de Zapata, "Comunicado de Emiliano Zapata a los miembros del ejercito libertador", 13 fev. 1915. Disponível em: <http://www.bibliotecas.tv/zapata/1915/z13feb15.htm>. Acesso em: 25 nov 2019.
} 
a Autoridade se robusteceu e os bandidos da política e do dinheiro roubaram descaradamente as terras, os bosques, tudo.

[...] o povo mexicano está apto para chegar ao comunismo, porque o tem praticado, ao menos em parte, desde vários séculos, e isso explica porque embora em sua maioria seja analfabeta, compreende que, melhor que fazer parte em farsas eleitorais para elevar verdugos, é preferível tomar possessão da terra e a está tomando, para o grande escândalo da ladrona burguesia. (FLORES MAGÓN, 1910, p. 1) ${ }^{28}$.

Ao chegar à questão da propriedade da terra, Flores Magón alcançou o problema de grande parte dos camponeses mexicanos que sofriam sob o porfirismo. Foi a prédica magonista que agregou densidade política às rebeliões camponesas, mas seu tom apocalíptico não proporcionou uma solução objetiva para os camponeses, embora tenha instrumentalizado ideologicamente a combatividade insurgente.

28 FLORES MAGÓN, Ricardo. El Pueblo Mexicano es apto para el comunismo. Regeneración, Los Angeles, n. 53, 2 set. 1911. 


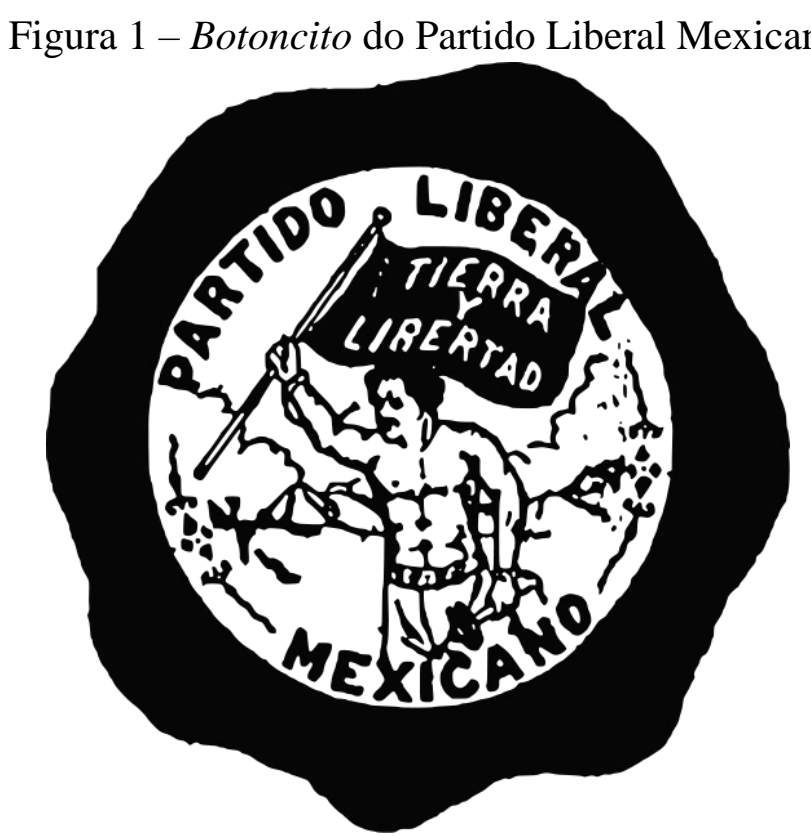

Fonte: Regeneración, n. 66, Los Angeles: 2 dez. 1911, p. 1

Aos 48 anos de idade, morreu Ricardo Flores Magón, depois de suportar mais de 13 anos de clausura em diferentes prisões nos EUA e no México. Manteve sua agitação por meio de Regeneración, mesmo dentro das piores condições de repressão política.

A câmara dos deputados, por ocasião da morte de Ricardo em uma prisão dos EUA em 1922, rendeu homenagens, que foram rechaçadas pelos companheiros anarquistas de Ricardo. Por outro lado, a confederação de sindicatos ferroviários trouxe por sua própria conta o corpo de Magón. Pelo caminho, operários prestaram diversas homenagens.

O magonismo não possuía um projeto de poder político nacional, mas a negação dos outros projetos em busca de um horizonte distante. Mais adiante, veremos que,

\footnotetext{
${ }^{29}$ Fonte: REGENERACIÓN, Los Angeles, n. 66, 2 dez. 1911, p. 1. Abaixo da gravura, aparece o seguinte texto: "Temos à venda botoncitos contendo a figura que reproduz a gravura. Cada botoncito vale 10 centavos ouro. Compre os botoncitos, pois tudo o que se reúna por esse meio servirá para o fomento da propaganda. O homem que sustenta a Bandeira vermelha é um trabalhador que acaba de fazer um esforço, tem rompido seus grilhões e se lança à luta contra o atual sistema. Na bandeira se pode ler com claridade o lema dos liberais mexicanos: Terra e Liberdade! Essa bela bandeira é a que nesses momentos aterroriza a burguesia e as autoridades em toda a extensão do território mexicano. $O$ botoncito constitui um meio de propaganda, pois ao vê-los nas blusas de nossos irmãos deserdados, muitos procuraram indagar pelo Partido e os princípios que o defende”.
} 
como Madero não solucionava a questão agrária, os zapatistas receberam influências da prédica magonista para manter suas reivindicações pela democratização da terra e para opor-se ao governo maderista.

No México, a oposição ao porfiriato se organizou em torno do liberalismo, reivindicando as conquistas juaristas. Os liberais mexicanos, diferentemente do que ocorreu em outras partes da América Latina, haviam alcançado maiores êxitos, emplacado importantes reformas e consolidado uma tradição política entre a intelectualidade marginalizada pela ditadura de Diaz. Essa influência liberal alcançou tamanha importância que de uma maneira ou de outra as correntes que se insurgiram durante a Revolução Mexicana (1910-1920) reivindicaram o liberalismo de Benito Juárez, ou as correntes mais populares e radicalizadas, como o zapatismo, inspiram-se em ideias facilmente associáveis à agitação anarquista, que nascem com a radicalização do programa do Partido Liberal Mexicano.

Porém, se a oposição liberal e anarquista foi mais densa no México, a repressão do Governo Diaz foi também mais violenta, a ponto de Ricardo Flores Magón passar parte de sua vida e atividade política entre o exílio norte-americano e a prisão.

A vitória do magonismo era irrealizável, mas o legado da agitação que promoveu alimentou outros movimentos, tornando-os mais combativos, encontrando na rebeldia a densidade doutrinária para sustentar projetos radicais em tempos anteriores à Revolução Russa de 1917, quando toda a alternativa social era apenas um projeto irrealizável.

\section{A Rebelião Zapatista}

O movimento revolucionário dirigido por Emiliano Zapata em Morelos foi provavelmente o movimento camponês mais bem-sucedido de toda a América Latina até a Segunda Guerra, por dois motivos: primeiro, chegou junto às tropas da Divisão Norte, comandadas por "Pancho" Villa, ao centro do poder político. Ambos chegaram a 
sentar na silla ${ }^{30}$ presidencial, tomaram a capital e derrotaram as tropas federais. No caso dos zapatistas, formulou-se o mais avançado programa de Revolução Agrária da época, o Plano de Ayala, e o defenderam de forma aguerrida e com clareza política os seus objetivos. O segundo motivo que torna a organização político-militar liderada por Zapata tão importante foi o seu legado para o movimento camponês mexicano posterior, inspirando o que seria denominado como agrarismo mexicano ${ }^{31}$, com várias vertentes, mas reivindicando uma mesma origem histórica. Pela importância que o zapatismo alcançou, a busca das origens do agrarismo se deu nas mais remotas origens

Os ejidos que sobreviveram e até conviveram com o domínio colonial espanhol se organizaram a partir de uma derivação dos calpullis nahuas na administração colonial espanhola. A propriedade da terra coletiva teria mantido uma certa autonomia política durante a administração colonial. Quando os liberais alcançaram o poder promoveram algumas reformas liberais e criaram alguns precedentes legais, com a chamada Ley Lerdo, que depois seria utilizada por Porfírio Diaz para transferir as terras comunais à exploração de cana-de-açúcar no Estado de Morelos.

Os dados desse processo de concentração de terra são muito conhecidos pela historiografia mexicana, e o ressentimento dessas comunidades transformadas em peones nas lavouras de açúcar e sem-terras teve um efeito de desagregação social. Assim teria nascido o movimento zapatista e explodiria a rebelião agrarista. Estudos recentes revelam que esse processo de desapropriação das terras comunais não foi gradativo, mas rápido e abrupto.

Os estudos mais recentes que originaram o movimento zapatista mostram que o conflito que ocorreu nos vales centrais morelenses no final do porfiriato não foi de tipo tradicional; não foi uma típica luta de povos e comunidades camponesas despejadas violentamente das suas terras por fazendas e

\footnotetext{
30 Silla em espanhol tem dois significados, que em português tem nomes bastante diferentes: significa tanto cadeira de sentar como cela para cavalos. A "silla" presidencial carregava um duplo sentido aos críticos do Governo: era a cadeira de onde o presidente montava e oprimia o povo.

${ }^{31} \mathrm{O}$ agrarismo mexicano após a Revolução se desenvolveu em várias direções, uma delas teve influência da Revolução Russa e do Partido Comunista, denominada por alguns autores como agrarismo rojo. A melhor descrição dessa experiência pode ser encontrada em: REINOSO, Irving. Machetes Rojos - El Partido Comunista y el Agrarismo radical (1919-1929), Morelos: UAEM, 2018.
} 
engenhos, senão que foi um conflito novo, produzido pela modernização tecnológica e produtiva da agroindústria da cana-de-açúcar. (AVILA, 2014, p.26).

Uma linha de pesquisa inovadora na época de sua publicação foi o livro de Womack $^{32}$, Zapata y La Revolucion Mexicana, publicado em 1969, em que o autor narra, a partir do contexto regional da política porfirista em Morelos, a rebelião zapatista, renunciando a esquemas "sociológicos abstratos", como as tentativas frustradas de enquadrar em classes abstratas as motivações do movimento. Uma das afirmações iniciais de Womack é de que os camponeses se rebelaram para não mudar, e encontraram mudanças ainda maiores, das quais fizeram parte. "Este é um livro acerca de camponeses que não queriam mudar e que por isso mesmo, fizeram uma revolução." (WOMACK, 1999, p. XI).

Como sugere a frase de Womack $^{33}$, foi comum na sociologia, inclusive marxista, a associação de movimentos camponeses ao conservadorismo, às forças retrogradas que, geralmente, quando se rebelaram, o fizeram para manter seus antigos direitos ${ }^{34}$.

O debate sobre as condições econômicas que possibilitaram a rebelião zapatista tem uma bibliografia extensa. Cabe destacar uma obra importante e atual que questionou alguns elementos da interpretação anterior. Horácio Crespo ${ }^{35}$ demonstrou que as mudanças econômicas vividas pelos camponeses de Morelos foram no sentido de modernização, de uma forma muito acelerada e abrupta, comparada as condições de transformação vividas no mesmo período na China e Rússia.

Frederich Katz organizou um livro com vários autores, publicado em 1998, em que buscou novas hipóteses para a explicação da rebeldia camponesa e sua tradição de

\footnotetext{
32 WOMACK JR., John, Zapata y la Revolución Mexicana, México DF: Siglo Veintiuno, 1999.

${ }^{33}$ Posteriormente Womack afirmaria que esse trecho havia sido mal interpretado.

34 “[...] de forma pouco clara e persistente se tem infiltrado a ideia, quase um dogma, de que os grupos camponeses, mais estritamente a classe camponesa não pode gerar um projeto global para a transformação da sociedade complexa" (WARMAN, Arturo. El Proyecto Político de Zapatismo. In: KATZ, Friedrich (compilador). Revuelta, Rebelión y Revolución - La Lucha Rural en México del Siglo XVI ao Siglo XX. México: ERA, 2008, p. 291).

${ }^{35}$ CRESPO, Horacio, Modernización y conflicto social. La hacienda azucarera en el estado de Morelos. México, INEHRM, 2009, pp. 126-145, 156-190, 359-379.
} 
violentos levantes. "Os camponeses mexicanos têm desempenhado um papel único na História da América Latina. O México é o único país do continente americano em que todas as transformações sociais têm estado vinculadas a levantamentos rurais." (KATZ, 2008, p. 18).

Outras linhas de pesquisa têm associado a rebelião zapatista a uma herança indígena $^{36}$, ou mesmo a uma tradição derivada do passado colonial ou pré-hispânico. A associação entre rebelião camponesa e o atraso encontra diversos matizes na historiografia. Há uma ideia muito arraigada, um pressuposto já muito naturalizado por uma parte da historiografia em que os camponeses aparecem sempre como incapazes de compreender e tomar decisões, sendo sempre assessorados por homens de outras origens sociais, os verdadeiros responsáveis por estruturar um programa político, as relações externas e as questões que não fossem diretamente ligadas aos problemas mais objetivos da produção e do campo militar.

Novos estudos, como os de Felipe Ávila e Pedro Salmerón, têm trazido novas perspectivas para a compreensão da Revolução Mexicana e para o papel dos exércitos populares, particularmente os liderados por Pancho Villa e Emiliano Zapata. Com novas fontes e problematizando antigos cânones da historiografia, os autores questionam os motivos da derrota de Villa e Zapata, bem como a tese da incapacidade programática dos camponeses e a "inevitável” vitória de Obregón. Salmerón faz uma análise, em um livro dedicado ao ano de 1915, o enfrentamento militar entre o constitucionalismo de Carranza-Obregón e os exércitos de Villa e Zapata.

\footnotetext{
${ }^{36}$ Desde que os militantes do EZLN se insurgiram em Chiapas, em meados da década de 1990, em meio às comunidades indígenas e reivindicando o termo zapatismo para o seu movimento, alguns autores exploraram a relação entre Emiliano Zapata e as comunidades indígenas. Na verdade, todo o México tem relação com os indígenas, de uma forma ou de outra, e a relação entre o movimento de Zapata em Morelos não teve nenhuma inspiração especial em formas de auto gestão indígena, mas de formas de organização do campesinato, que no México, está vinculado aos indígenas. Alguns ressaltaram que o localismo que teria caracterizado os zapatistas seria de origem indígena. Sobre isso, ver: Natividad Gutierrez Chong, "Mitos nacionalistas e Identidades étnicas: los intelectuales indígenas y el Estado Mexicano"; ver também GIL, Antonio Carlos Amador. "As alternativas políticas que o zapatismo operacionaliza na América Latina contemporânea. Um caso de História do tempo Presente", Dimensões, vol 17, Vitória: 2005, p. 117-131.
} 
Com essas perspectivas renovadas, Ávila e Salmerón reconhecem a influência magonista, na radicalização do zapatismo, admitindo, portanto, a capacidade de elaboração política dos chefes revolucionários de origem camponesa e popular.

\begin{abstract}
Por ese motivo no reconocerían a ningún gobierno que no avalara previamente la justicia de su lucha. Y, debido a la influencia del pensamiento anarquista que era el paradigma ideológico de varios de los intelectuales urbanos que se habían incorporado a sus filas, expresaron por primera vez su rechazo a las elecciones y a los cambios meramente políticos: "puede haber elecciones cuantas veces se quiera, pueden asaltar, como Huerta, otros hombres la silla presidencial, valiéndose de la fuerza armada o de la farsa electoral... no arriaremos nuestra bandera ni cejaremos un instante en la lucha hasta que, victoriosos, podamos garantizar con nuestra propia cabeza el advenimiento de una era de paz que tenga por base la justicia y como consecuencia la libertad económica... sépase de una vez por todas que no luchamos contra Huerta únicamente, sino contra todos los gobernantes y conservadores enemigos de la hueste reformista". Su compromiso era dar pan a los desheredados y construir una patria libre. (AVILA e SALMERÓN, 2014, p.187).
\end{abstract}

O reconhecimento da permeabilidade de ideias políticas que animavam o movimento operário europeu entre as tropas zapatistas e villistas serve para afastar a pecha da ignorância e do simplismo que se atribui aos comandantes revolucionários. A perspectiva de Ávila e Salmeron demonstra como as diversas correntes políticas que se enfrentaram na Revolução opuseram programas políticos, e a vitória de um e a derrota de outros não se deu pela inexistência de um projeto popular, como muitas vezes se previu. O plano de Ayala e o programa de reformas villistas e zapatistas, além da própria Convenção são provas disso. ${ }^{37}$

O chamado às armas de Madero, marco oficial da Revolução Mexicana, foi herdeiro direto do movimento liberal, e, de uma maneira ou de outra, todos os movimentos que resistiram ao porfiriato estavam vinculados aos clubes liberais.

Madero representava o liberalismo das classes abastadas, com um programa de reformas democráticas limitadas e que não tocavam de maneira significativa na questão

${ }^{37}$ Felipe Ávila escreve sobre a Convenção de Aguascalientes e os projetos em disputa, em: ÁVILA ESPINOSA, Felipe Erturo. Las corrientes revolucionarias y la soberana, México: INEHRM, 2017. 
agrária, exceto pelo artigo $3^{\circ}$ no parágrafo 3 do Plano de San Luis de Potosi, em que se dizia:

\begin{abstract}
Abusando da lei dos terrenos baldios, numerosos pequenos proprietários, na maioria indígenas, foram despojados de seus terrenos, por decisão da secretaria de Fomento ou por falha dos tribunais da República. Sendo de toda justiça restituir a seus antigos possuidores os terrenos de que se despojou de um modo tão arbitrário, se declaram sujeitas a revisões tais disposições e falhas, e se exigirá aos que os adquiriram de um modo tão imoral ou a seus herdeiros, que os restituam a seus primitivos proprietários, a quem pagarão também uma indenização pelos prejuízos sofridos. Só em caso em que esses terrenos tenham passado a terceiras pessoas antes da promulgação deste plano, os antigos proprietários receberão indenizações daqueles em cujo benefício se verificou o despojo. (MADERO, 1910³).
\end{abstract}

A parte mais radicalizada do movimento liberal estava vinculada ao Jornal Regeneración de Ricardo Flores Magón, que naquele tempo já fazia propaganda abertamente anarquista. Foi essa propaganda que chegou a Morelos, foram essas ideias, que desconheciam a propriedade privada, que olhavam com desconfiança os governos e que chamavam para a ação direta os trabalhadores, que consolidaram a intransigência zapatista frente às negociações contra as diversas facções revolucionárias e que possibilitaram maturidade e clareza política aos chefes militares para não desarmarem seus exércitos e aceitarem os engodos e as promessas. A influência da propaganda anarquista para os revolucionários zapatistas é clara, e entre os primeiros historiadores que trataram a Revolução, como Jesus Herzog, que teve participação nas batalhas, chegou a afirmar:

O autor deste livro pode assegurar, porque constatou pessoalmente que muitos chefes revolucionários na etapa constitucionalista da Revolução conheciam bem o manifesto e o programa do PLM e que indubitavelmente influiu em seu pensamento [...]. Os autores do documento político que citamos continuaram, depois da distribuição do mesmo, semeando ideias de inconformidade e agitando a massa trabalhadora por meio do jornal Regeneración, que publicavam nos EUA e que era enviado pelo correio aos assinantes no México. (HERZOG, 1988, p. 69).

${ }^{38}$ MADERO, Francisco. Plano de San Luis de Potosi. San Luis de Potosi, 5 out. 1910. Disponível em: <http://es.wikisource.org/wiki/Plan_de_San_Luis_Potos\%C3\%AD>. Acesso em: 30 mar 2014. 
O magonismo chegou em Ayala pelos intelectuais liberais radicais, influenciados pelo anarquismo de Regeneración.

Para os camponeses, a reinvindicação imediata estava clara: democratização do acesso à terra, principal meio de subsistência do campesinato. A prédica anarquista, que a princípio parece mais adequada a uma realidade fabril, vestia como uma luva o tipo de luta que os camponeses buscavam organizar, embora não em uma totalidade lógica e doutrinária, mas, principalmente, em aspectos da crítica contra a propriedade privada, a opressão do Estado e na ação direta como método de luta.

Não foram os anarquistas que influenciaram os camponeses, se tomamos como referência a ideia comumente passiva de quem é influenciado. Foram os camponeses que "escolheram"39 entre as ideologias que melhor poderiam armá-los subjetivamente para a luta em torno de suas demandas. O Plano de Ayala, que Womack chama de a "sagrada escritura" zapatista, é o documento fundador, e é defendido em todo processo da luta como programa do Estado Maior zapatista. Nenhum documento é melhor para analisarmos o zapatismo.

O Plano de Ayala foi assinado pelos comandantes militares que representavam a rebelião de Morelos e os quais, depois de várias tentativas em garantir o cumprimento efetivo da parte do Plano de San Luis de Potosi, que prometia a restituição das terras usurpadas pelo porfirismo, decidem-se em iniciar a luta armada novamente, agora contra Francisco Madero. O Plano zapatista começa desconhecendo Madero e colocando a traição maderista como justificativa para o levante. O tom de pronunciamento público contrasta com as soluções práticas e antiburocráticas: como

\footnotetext{
${ }^{39}$ Aqui não estamos tratando de "ideologias" como um corpo fechado e absolutamente coerente de ideias, mas de concepções políticas que imprimem uma direção, que tem uma história e uma origem, mas também se adaptam e se ressignificam em contextos políticos novos. E nesse sentido, cabe a reflexão de Geraldo Leibner ao tratar o mito do socialismo indígena no Peru: "A estas interpretações, produto do afã por enclausurar ou ao menos classificar pensadores latino-americanos originais em categorias ideológicas europeias, quero opor uma interpretação que parte do rechaço do conceito de "influência ideológica". As ideias criadas em outra sociedade e em outras circunstâncias não influem simplesmente sobre o pensador, senão que é ele quem as escolhe quando elas respondem a certas necessidades de reflexão." (LEIBNER, 1999, p. 12, a tradução é nossa).
} 
definir como um dos critérios para a expropriação das terras a opções que cada latifundiário faça entre o apoio ou não a Revolução: "Os fazendeiros, científicos ou caciques que se oponham direta ou indiretamente ao presente Plano, se nacionalizarão seus bens". (PLANO DE AYALA, 1911, s.p.).

O que define e caracteriza o documento zapatista é a sua forma de tratar a questão da propriedade privada da terra, não como direito individual, mas pela sua função social, sujeita à expropriação em nome da melhoria, da prosperidade e do bemestar dos mexicanos. Nesse ponto, os camponeses zapatistas se afastavam da sacralização liberal da propriedade privada e se aproximam do magonismo, que denunciava a propriedade privada, junto ao Estado e à Igreja, como os grandes males da sociedade.

(...) Em virtude de que a maioria das comunidades e cidadãos mexicanos não são mais donas do território onde pisam, sem poderem melhorar em nada a sua condição social, nem poderem se dedicar à indústria ou a agricultura, por estas estarem monopolizadas por umas quantas mãos, as terras, montes e águas; por esta causa se expropriarão prévia indenização, da terceira parte desses monopólios, aos poderosos proprietários deles a fim de que os povos e cidadãos do México obtenham ejidos, colônias, fundos legais para comunidades ou campos para semear ou trabalhar e se melhore em tudo e pata tudo a falta de prosperidade e bem-estar aos mexicanos. (Ibidem, s.p.).

O corte imediato das propriedades expropriadas pelos zapatistas são similares à perspectiva da Ação Direta anarco-sindicalista e fizeram parte fundamental da agitação magonista ${ }^{40}$.

\footnotetext{
${ }^{40}$ Em 1918, o zapatismo tinha claros os meios para conquistar a terra, próximo da propagada Ação Direta anarquista: "En cambio, la revolución ha hecho promesas concretas, y las clases humildes han comprobado con la experiencia, que se hacen efectivos esos procedimientos. La revolución reparte tierras a los campesinos, y procura mejorar la condición de los obreros citadinos; nadie desconoce esta gran verdad. En la región ocupada por la revolución no existen haciendas ni latifundios, porque el Cuartel General ha llevado a cabo su fraccionamiento en favor de los necesitados, aparte de la devolución de sus ejidos y fundos legales, hecha a las poblaciones y demás comunidades vecinales". In: ZAPATA, Emiliano. Manifiesto de Zapata: Llamamiento patriótico a todos los pueblos engañados, Tlaltizapán, 22 ago. 1918 Disponível em: <http://www.bibliotecas.tv/zapata/1918/1918.html>. Acesso em: 25 nov 2019.
} 
(...) que os terrenos, montes e águas que os fazendeiros, científicos ou caciques tenham usurpado à sombra da justiça venal ficarão em posse desses bens imóveis desde logo, as comunidades ou cidadãos que tenham seus títulos, correspondentes a essas propriedades, das quais tem sido despojados pela má fé de nossos opressores, mantendo em todo o processo, as armas nas mãos, durante mencionada posse. E os usurpadores que se considerem com direitos a eles, o deduzirão ante aos tribunais especiais que se estabeleçam com o triunfo da Revolução. (Ibidem, s.p.).

Segundo Salmerón, a contribuição central do Plano de Ayala e sua originalidade foi tentar resolver o problema do campo através da via revolucionária, mediante a ocupação da terra pelos pueblos e a sua defesa com as armas na mão. (SALMERÓN, 2015a).

A desconfiança frente aos governos foi talvez o mais importante aprendizado de ciência política absorvido pelo Estado Maior zapatista da experiência e agitação política magonista, mas padeceu da mesma falha que os anarquistas em outros contextos históricos. A agitação revolucionária em busca da sociedade sem classes não possuía um meio-termo de ordem social que possa servir de acúmulo de forças, ou estágio antes da sociedade sem classes, a anarquia. Ao renunciar a autoridade, ao Estado no entendimento mais amplo anarquista, se renuncia a capacidade militar, se renuncia a uma centralização e organização política capaz de manter as mudanças sociais da revolução.

Outras correntes radicais do movimento operário, como no caso dos comunistas, em várias situações estavam abertas diversas possibilidades, desde a participação política no parlamento, como forma de acumulação de forças e conquistas parciais, até a ditadura do proletariado; a transição socialista até o comunismo. Para os comunistas, mesmo quando defendiam meios radicais e agitaram a luta armada e a insurreição revolucionária, apresentaram o que foi chamado de programa mínimo da revolução, com medidas imediatas e um plano de transição até a sociedade comunista, a sociedade sem classes ${ }^{41}$.

\footnotetext{
${ }^{41}$ Cabe destacar que Marx e Engels se identificaram originalmente com o nome comunismo, mas é com Lenin e a Internacional Comunista que o nome comunismo ganha identidade particular, seria sinônimo de marxismo-leninismo e suas derivações posteriores. Durante as importantes batalhas travadas pelo
} 
As principais correntes anarquistas que tiveram eco no México propagaram uma perspectiva apocalíptica e de ruptura revolucionária, em que a velha sociedade daria lugar a nova, em todos os lugares e em todos os aspectos. Nessa perspectiva, não era possível nenhum recuo tático, e assim, não chegando à sociedade anarquista, só restavam a derrota e o aniquilamento. A influência magonista não é, portanto, programática.

Se nos basearmos nos principais interpretes da revolução que trataram o zapatismo e o villismo como importantes correntes da revolução, como Córdova, Brunk, Womack, Herzog e mesmo Katz, é possível concluir que os camponeses de Morelos, e o villismo não possuíam um programa para toda a nação, capaz de vencer politicamente o constitucionalismo. Essa é uma prerrogativa generalizada na historiografia.

As obras de Felipe Ávila, e particularmente o livro de Pedro Salmerón (2015), trataram com ênfase o ano de 1915, o ano de confronto entre as correntes convencionistas (zapatistas e villistas) e o constititucionalismo (carrancistas e obregonistas). Embora Ávila e Salmerón questionem com fontes novas e importantes a teoria da "inevitável" ${ }^{42}$ derrota camponesa, é possível verificar que o problema se mantém, mesmo com os dados e a interpretação dos autores. Salmerón parece confundir capacidade militar, política e intelectual dos dirigentes camponeses e populares, com uma via camponesa de revolução, ou seja, confunde a subestimação de homens de origem camponesa com a viabilidade nacional do programa camponês. Se tomarmos como exemplo o programa anarquista, fica clara a diferença entre a importância para a mobilização política e a capacidade dos anarquistas em implantar seu programa revolucionário. O caso da derrota zapatista, e a posterior cooptação de líderes zapatistas após o assassinato de Zapata em 1919, parece indicar que a aplicação do programa agrário não gera condições para o enfrentamento das outras correntes, como a de

zapatismo, o comunismo não era uma corrente do movimento operário ainda.

42 SALMERÓN, 2015a; SALMERÓN, 2015b; ÁVILA ESPINOSA, 2014; ÁVILA ESPINOSA e SALMERÓN, 2015. 
Obregón e Carranza, que procuraram manter o controle e definir uma direção para outras atividades produtivas no país, como o papel estratégico do petróleo. O fato de programa zapatista não responder a uma perspectiva nacional e as questões estratégicas, demonstra uma debilidade fundamental, porque define a capacidade militar, política e o alcance social do movimento camponês.

Essa diferença fica clara em Salmerón ${ }^{43}$. O autor questiona a subestimação insistente da capacidade de Zapata e Villa, seja no plano militar, ao eleger Felipe Angeles como estrategista das vitória villistas ou outros fatores, especialmente militares. Ávila demonstra que a aplicação da Revolução Agrária zapatista em Morelos criou uma situação econômica insustentável para a manutenção da guerra pelo Exército libertador do Sul.

O programa de pequenas propriedades ou propriedades ejidais zapatistas não fornecia uma base de sustentação econômica capaz de manter o novo Estado e uma revolução.

Su decisión de no marchar hacia el sur y replegarse a su territorio había sido de enormes consecuencias porque el constitucionalismo aprovechó la entrega de la ciudad de México y la rendición del ejército federal para fortalecerse enormemente, conquistando los territorios de buena parte del centro y sur de la república y quedándose con el enorme arsenal militar del ejército federal y el control de zonas económicas estratégicas para la guerra que se venía. (...) Sin embargo, en la práctica política y en la ideología de las fuerzas

\footnotetext{
43 "Esta fatalidad histórica impregna prácticamente toda la historiografía posterior y junto con el “canon historiográfico", domina por completo nuestra idea de la guerra civil de 1915: la imposibilidad de los campesinos para ganar la guerra. Pero antes de ir a esa fatalidad histórica, digamos que podríamos empezar de otra forma. Y es que para los historiadores de los setenta, la derrota de la revolución campesina no fue total: muchas de sus demandas fueron retomadas por el sector radical (obregonista) del constitucionalismo, y se manifestaron en el Congreso Constituyente de 1917. Por lo tanto, explicar la guerra civil de 1915 es explicar las formas y las razones de su victoria y también, el diseño del país que vivimos después de 1920, fundado en un marco legal que no se entiende sin esa victoria y las formas de esa victoria. Un marco legal que está siendo destruido, de espaldas a la nación, al momento en que escribo estas líneas.

Regresemos a la "fatalidad histórica": muchas veces se ha contado la historia de la guerra civil de 1915 o "lucha de facciones", sin embargo, la mayoría de sus interpretaciones coinciden en lo esencial respecto del punto crucial, en la pregunta detonante de esta historia: ¿Por qué perdieron Zapata y Villa? (SALMERÓN, 2015a, s/p).
} 
integrantes de la coalición convencionista existía una menor unificación y una mayor heterogeneidad que en la de sus adversarios. Tal vez ése era su punto neurálgico más débil. El constitucionalismo, por su parte, en términos militares estaba muy equilibrado con las fuerzas de la Convención, como se detallará un poco más adelante; pero en el terreno político e ideológico mostraba un mayor agrupamiento y homogeneidad. La salida del sector más proclive a las reformas sociales y el fallido intento de la tendencia obregonista por llegar a un acuerdo con los convencionistas habían fortalecido el liderazgo con Carranza y las voces disidentes se acallarían por un buen rato. Para el enfrentamiento inmediato se hallaban bien agrupadas y era más fácil que desarrollaran un plan de guerra y político único. (ÀVILA, 2017, p.346-347).

Quando alcançou representatividade, o movimento revolucionário camponês sustentou uma grande combatividade, mas, ao mesmo tempo, não conseguiu constituir um programa mínimo, um programa imediato para toda a nação. Quando alcançaram o poder central, não conseguiram manter o poder, e nem derrotar as forças contrárias, o constitucionalismo. Outras forças políticas com propostas imediatas conquistam as bases sociais do movimento, isolaram os líderes mais radicais e a resistência foi eliminada com repressão. Assim ocorreu com as forças zapatistas e villistas, que, ao chegarem à cadeira presidencial, com o controle do território e o poder militar, não conseguiram impor um programa, apenas mantiveram a disposição de lutar contra uma tirania que oscilava entre abstração e personalismo. Entre os zapatistas, manteve-se sempre como fim a Revolução Agrária. Zapata e Villa tomaram o poder sob custódia, mas não tinham planos para a consolidação da revolução. Vale destacar, como demonstra Ávila e Salmerón, que não ter planos para a consolidação da revolução não significa não ter objetivos revolucionários. Diversos decretos, planos e leis elaboradas por zapatistas e villistas significaram mudanças sociais profundas e revolucionárias, mas tais mudanças não garantiram bases sociais capazes de sustentar o poder.

A ideia de revolução sustentada pelo zapatismo requer atenção. Parece claro que para Emiliano Zapata havia uma clara distinção entre a tomada do governo e a tomada do poder. A transcrição da conversa entre Zapata e Villa em Xochimilco ilustra com claridade esse ponto. O governo era concebido como um instrumento de opressão pelo seu centralismo, pelo seu controle por uma casta profissional desarraigada do povo, por sua natureza repressiva e expropriatória. O governo concebe-se como uma camisa de força para a 
revolução; a condenava a repetir práticas opressivas em virtude de que todo aparato governamental estava orientado nessa direção. O problema da revolução não era a captura do governo, senão a sua dissolução para proceder a reformulação do Estado. A revolução era concebida como um processo e não como um ato de tomada de controle. O processo revolucionário devia desenvolver-se na base da sociedade e não pelo alto. A transformação da existência, estabelecida e defendida com as armas, devia preceder a transformação do Estado, só assim seria definitivo, irreversível. Primeiro devia entregar a terra, o poder militar e a autonomia política às unidades constitutivas da sociedade, para refazer o Estado como uma unidade coletiva de serviço. (WARMAN, 2008, p. 305) ${ }^{44}$.

Nos últimos anos antes de seu assassinato, o linguajar das declarações do Estado Maior zapatista estava tão próximo da agitação magonista que seria pouco provável, como diria Womack (1999, p. 397), que alguma outra facção revolucionária pudesse se aliar aos zapatistas que não fossem os anarquistas.

O vínculo entre magonismo, anarquismo e zapatismo apontado por Herzog foi poucas vezes citado pela historiografia. Essa ideia seria retomada principalmente pelas obras de Felipe Ávila.

${ }^{44}$ WARMAN, Arturo. El Proyecto Político de Zapatismo. In: KATZ, Friedrich (compilador). Revuelta, Rebelión y Revolución - La Lucha Rural en México del Siglo XVI ao Siglo XX. México: ERA, 2008. 
FIGURA 2 - Francisco "Pancho" Villa na silla presidencial, ao lado de Zapata ${ }^{45}$

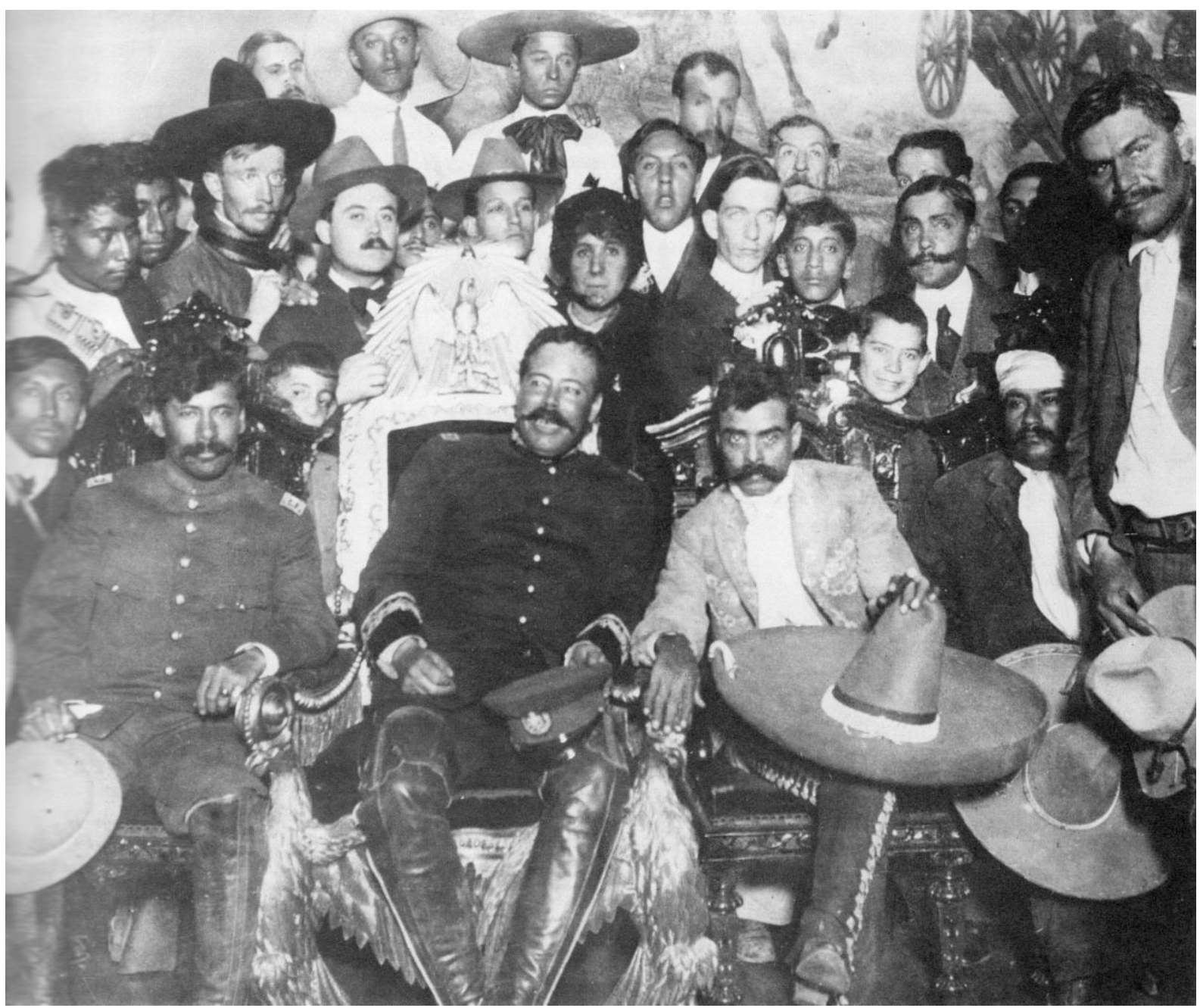

Fonte: Arquivo fotográfico Casasola

O habitat do anarquismo não poderia ser o Estado, mas na oposição a ele. Assim, quando Zapata e Villa passaram novamente à resistência guerrilheira contra as tropas constitucionalistas, a partir de 1915, suas posições se aproximassem ainda mais às anarquistas, e cada vez menos aos antigos liberais. Esses últimos, a essa altura, já estavam compondo o novo governo, discutindo a nova constituição e disputando

\footnotetext{
${ }^{45}$ Fonte: Archivo fotográfico Casasola, "Francisco Villa em la Silla presidencial", fundo Casasola, autor Casasola, México, 6 dez. $1914 . \quad$ Disponível <http://www.sinafo.inah.gob.mx/galerias/fotoperiodismo/fotoperiodismo.swf>. Acesso em:
}

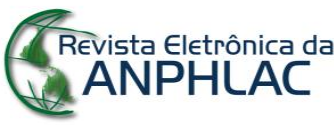


espaços nos governos regionais que se reestruturavam a partir das lutas entre facções do constitucionalismo.

El zapatismo convirtió sus manifiestos y proclamas en una tribuna para denunciar al régimen y al sistema social y para llamar a la unión de los desposeídos. El movimiento zapatista demostró que tenía una obsesión por la palabra escrita, por hacer púbico su pensamiento y sus acciones, por hacerse escuchar y romper el silencio en que los pueblos y comunidades habían estado por largo tiempo. El discurso que esgrimieron sus ideólogos era uno de combate, incendiario, con un contenido y una forma que tenían ecos magonistas. No en balde varios de los nuevos e influyentes asesores civiles, como Antonio Díaz Soto y Gama, provenían de esa corriente. (ÁVILA, 2014, p.189).

O espaço de desenvolvimento do zapatismo estava cada vez mais relacionado ao movimento operário e ao magonismo desses anos. Ricardo Flores Magón, inclusive, só reconheceria como verdadeiros revolucionários os que lutavam ao lado de Zapata.

Um dos mais interessantes documentos assinados por Zapata e que demonstra com clareza a separação dele de toda a tradição liberal e seu esforço por aliar-se aos operários está no documento dirigido aos operários, redigido desde o quartel general zapatista, em 15 de março de 1918.

\begin{abstract}
Falaz e astuto, o carrancismo, essa burguesia uniformizada de amarelo envolto de cartucheiras, vestiu ontem a roupa da fábrica e fingiu [...] A ilusão foi cruel e não se fez esperar. Em vez da ajuda prometida aos seus sindicatos, veio a imposição governativa, exigente e tirânica; se quis fazer do operário a criatura dócil do governo, para preparar quando a farsa das eleições chegasse, a exaltação ao dos cupinchas do carrancismo, ou seja, se quis transformá-los em uma arma que servisse à tirania e a seu aliado, o capital, nada menos que dos sindicatos, ou seja as agrupações criadas para defender o trabalho contra as espoliações e abusos desse mesmo capital, e por haver querido resistir a essa pressão governativa, vocês o sabem, o carrancismo chegou onde o próprio Huerta não chegou, a fechar as suas casas, os seus templos de liberdades, a Casa do Operário Mundial! Não foi tudo, bem sabem; quando a greve veio, os negou o direito de greve, em vez dos patrões o fazer, Carranza impôs suas condições, de acordo, claro, com eles. E como se não fosse o bastante: aos que protestaram, a prisão! Como se não fosse demasiado, aos que resistiram, a forca! Querem mais? Querem maior infâmia! (ZAPATA, 1918 , s.p. $)^{46}$
\end{abstract}

46 ZAPATA, Emiliano. A los obreros de la república, Tlaltizapán, 15 mar. 1918. Disponível em: <http://www.bibliotecas.tv/zapata/1918/z15mar18a.html>. Acesso em: 27 mar 2014. 
Podemos encontrar, em menor grau, as influências do anarquismo nas decisões do Comandante da Divisão Norte, Francisco Villa, que continham essa mesma característica antiburocrática, de soluções pouco comuns à tradição da administração estatal na América Latina.

Uma característica do documento zapatista que evidencia um desprezo pela lógica burocrática do Estado está na afirmação da decisão municipal em detrimento da imposição estatal central. Foi característica do zapatismo a valorização pelas decisões locais, no âmbito dos pueblos, longe dos "corruptos" do poder central, e carregado da sabedoria da experiência cotidiana da vida municipal, em que todos se conheciam e mantinham outras formas de mediação e convivência.

Embora o anarquismo seja peça-chave para se entender o a ideologia zapatista, essa influência não é reconhecida nominalmente pelos próprios, nem o termo "anarquia" ou "anarquista" tem conotação positiva. A palavra "anarquia" chegou antes do movimento anarquista nas Américas. Em um pequeno trecho do Plano de Ayala, anarquia aparece com a conotação pejorativa e sinônimo de desordem:

[...] pues ha sido claro y patente que ha ultrajado la soberanía de los Estados, conculcando las leyes sin ningún respeto a vida ni intereses, como ha sucedido en el Estado de Morelos y otros conduciéndonos a la más horrorosa anarquía que registra la historia contemporânea (PLANO DE AYALA, 1911, s/p., grifo nosso $)^{47}$.

\footnotetext{
${ }^{47}$ Acreditamos que ao longo da Revolução, de 1911 até 1918, o Estado-Maior zapatista tenha modificado sua percepção acerca do sentido da palavra anarquismo. Em nosso modo de ver, as palavras não têm um significado único para todos os contextos. Os homens se apropriam das palavras, dando significados diferentes no tempo e espaço. Em meio aos movimentos emancipatórios, frente às intensas lutas políticas, uma mesma palavra pode ter um significado para um, e outro para um grupo diferente em uma mesma época, além de ter conotações distintas em cada época e lugar. Por outro lado, o Plano de Ayala é do início da década, e tudo leva a crer que o Estado-Maior zapatista foi se aproximando de antigos membros do PLM, como Soto y Gama, o que nos faz pensar que, se houvesse uma "revisão" do Plano de Ayala por Zapata nos anos de 1917-8, certamente esse trecho "horrorosa anarquia" seria suprimido. Zapata não foi anarquista, e aqui não nos importa definir um simples rótulo, mas, acima de tudo, demonstrar como a agitação anarquista influenciou um movimento camponês revolucionário com características particulares, e como essa tradição política radical será retomada pelo PCM na década de 1920.
} 
Como conclusão, e na direção das recentes pesquisas de Pedro Salmerón e Felipe Ávila, foram diversas as influências e contextos que condicionaram a rebelião camponesa. O liberalismo, como diversas correntes de pensamento político, inspirou os movimentos populares e encontrou a dinâmica da luta popular. Os atores não absorvem passivamente ideologias e programas, mas dão nova significação, incorporam uma outra densidade e novas perspectivas.

Retomando a questão colocada no início, sobre as reflexões de José Aricó acerca das dificuldades do socialismo na América Latina, em comparação com a história europeia, o magonismo e o zapatismo são claras demonstrações de como a história política na América Latina pode trazer combinações e sentidos bastante diversos do referente metropolitano.

Essa não é uma questão nova, o espelhismo já foi muitas vezes tema de críticas na historiografia latino-americana. É necessário propor as novas possibilidades, pensar relações e avançar com na pesquisa documental.

\section{Referências Bibliograficas:}

AMIN, Samir e VERGOPOUlOS, Kostas. La Cuestión Campesina y el Capitalismo, México, D.F.: Nuestro Tiempo, 1980.

ÁVILA ESPINOSA, Felipe Arturo, Las corrientes revolucionarias y la soberana convención, México: INEHRM/Colégio de México/UAAC, 2014.

ÁVILA ESPINOSA, Felipe Arturo; SALMERÓN, Pedro. Historia breve de la Revolución Mexicana. México: SEP/INEHRM/Siglo Veintiuno, 2015.

BARBOSA, Carlos Alberto Sampaio. A Revolução Mexicana, São Paulo: UNESP, 2010.

BARRIOS, Elias. El Escuadrón de Hierro, México: Cultura Popular, 1978.

BETHELL, Leslie (org.) História de América Latina, 15 tomos, Barcelona: Crítica, 1990

BRADING, David. Los Orígenes del Nacionalismo Mexicano, México: ERA, 2004.

BRUNK, Samuel, Zapata, Revolution and Betrayal in Mexico, Albuquerque, University of New Mexico Press, 1992. 
CAMACHO, Manuel. La Classe Obrera em La História de México - el futuro imediato, v.15, México: Siglo Veintiuno, 1980.

CAMIN. Héctor Aguilar, Saldos de la Revolución-Cultura e Política de México 19101980, México, DF.:Nueva Imagem, 1982.

CARR, Barry. La Izquierda Mexicana a través del siglo XX, México: ERA, 1996.

CARR, Barry. El Movimiento Obrero y la política en México - 1910-29, México: ERA, 1976.

CARR, E. H. La Revolución Bolchevique 1917-1923. 1. La Conquista y Organización del poder, Madre: Alianza Universidad, 1977.

CARR, E. H. Estudios sobre la revolución, Madrid: Alianza Editorial, 1968.

CASAL, Juan Manuel. Mariátegui: El Socialismo Indoamericano, Montevideo: Proyección, 1992.

CENTRO, de Estudios Históricos del Movimiento Obrero Mexicano. El Movimiento Obrero Mexicano - Bibliografia, México: CEHSMO, 1978.

CHAVOLlA, Arturo, La Imagen de América en el Marxismo, Buenos Aires: Prometeo, 2005.

CLARK, Ruth. La organización obrera en México, México, DF.: ERA, 1981, 244 p.

COCKCROFT, James. Precursores Intelectuales de La Revolución Mexicana (19001913), México, D.F.: Siglo Veintiuno, 1981.

CORDOVA, Arnaldo. La Ideología de La Revolución Mexicana - La Formación del nuevo Régimen, México, D.F.: ERA, 1991.

CORDOVA, Arnaldo. La Política de Masas del Cardenismo, México: ERA, 1974.

DE LA PEÑA, Sergio e AGUIRRE, Teresa. De la Revolución a la Industrialización, Coord. Enrique Semo, México: Océano, 2006.

DONGHI, Túlio Halperin. História da América Latina; Trad. C.N.Coutinho, Rio de Janeiro: Paz e Terra, 1975.

DULlES, John W.F. Anarquistas e Comunistas no Brasil. Rio de Janeiro: Nova Fronteira, 1977.

DULLES, John W.F. Ayer en México, Una Crónica de La Revolución (1919-1936), México: FCE, 2003.

FALCÓN, Jorge. Anatomía de los Siete Ensayos, Lima: Amauta, 1978.

FALCÓN, Jorge. Mariátegui: la Revolución Mexicana y el estado “anti”-imperialista, Lima; Amauta, 1980.

FLORES MAGÓN, Ricardo. A Revolução Mexicana, São Paulo: IEL - Imaginário, 2003. 
FLORES MAGÓN, Ricardo. Obras Completas de Flores Magón. Disponível em: http://www.archivomagon.net, acesso em: 08 nov 2019.

FLORES MAGÓN, Ricardo. Su Vida y su obra, 42 cartas escritas en Ingles durante los dos últimos años de prisión y su vida, México: Editores Mexicanos Unidos, 1976.

FLORESCANO, Enrique. El Nuevo Pasado Mexicano, México: Cal y Arena, 2009.

GARCILADIEGO, Javier, Textos de la Revolucioón Mexicana, Caracas: Biblioteca Ayacucho, 2010.

GIL, Mario. México y la Revolución de octubre, México: Cultura Popular, 1978.

GILLY, Adolfo. Felipe Angeles en La Revolución, México: ERA, 2008.

GILLY, Adolfo. Revolución Interrumpida: Una Guerra Campesina por Tierra y El Poder, México, D.F: Ediciones "El Caballito", 1980.

GONZÁLEZ CASANOVA, Pablo. La Classe Obrera em La História de México - en el primer gobierno Constitucional (1917-1920), v.6, México: Siglo Veintiuno, 1980.

GONZÁLEZ PRADA, Paginas Libres y Horas de Lucha. Edição digital, s/l., s/d

GUZMAN, Martín Luis. El Aguila y la Serpiente, México: CGE, 1965.

GUZMAN, Martín Luis. Memorias de Pancho Villa, México: s/ed., 1970.

HAMZA ALAVI. Teoria de la Revolución Campesina, México, ENAH, sd.

LEIBNER, Geraldo. El Mito del Socialismo Indígena en Mariátegui, Lima: Fondo Editorial-PUC, 1999.

MANCHISIDOR, José. Sintesis Histórica del Movimiento Social en México, México: CEHSMO, 1976.

MATUTE, Álvaro, Historia de la Revolución Mexicana, 1917-1924: las dificultades del Nuevo Estado, México, D.F.: El Colegio de México, 1995.

MATUTE, Álvaro. La revolución Mexicana: Actores, escenarios y acciones - Vida Cultural y política. 1901-1929, México: INEHRM, 2002.

MEYER, Jean. El Campesino en La Historia Rusa y Sovietica. México: FCE, 1996.

MEYER, Jean. La Cristiada - La Guerra de los Cristeros, México DF., Siglo Veintiuno, 1973.

PASSOS GUIMARÃES, A. As Classes Perigosas: banditismo urbano e rural, Rio de Janeiro: UFRJ, 2008.

PAZ SOLÓRZANO, Octavio. Emiliano Zapata, México: FCE, 2012.

POSADA, José Guadalupe. Monografia de 406 grabados. Con la introducción de Diego Rivera. México: RM, 2012. 
RAMA, Carlos. Historia del Movimiento Obrero y Social Latinoamericano Contemporaneo, Barcelona: Laia, 1976.

RUIZ, Ramón Eduardo. La Revolución Mexicana y el Movimiento Obrero (1911-1923), México: ERA, 1976.

SAENZ, Aaron. La politica Internacional de la Revolución, Estudios y Documentos, México: FCE, 1961.

SALMERÓN, Pedro. 1915 - México em Guerra, México: Planeta, 2015ª

SALMERÓN, Pedro. Juárez, La Guerra Interminable, México: Planeta, 2015b.

SAMIR AMIN, La Cuestión Campesina y el Capitalismo, México: Nuestro Tiempo, 1980.

SAMIS, Alexandre. "Apresentação" In: FLORES MAGÓN, Ricardo. A Revolução Mexicana, São Paulo: IEL - Imaginário, 2003.

SANTILLÁN, Diego Abad de. "México Libertário" in FLORES MAGÓN, Flores. Ricardo Flores Magón. O Apostolo da Revolução Mexicana, Rio de Janeiro: Achiamés, s/d.

SANTOS, Fabio Luis Barbosa dos. "O magonismo e a Revolução Mexicana", Revista de História. nº166, São Paulo: p. 285-309, jan./jun. 2012.

SEMO, Enrique (coordenador). História de la Cuestión Agrária Mexicana, 4 tomos, México, Siglo Veintiuno, 1988.

SILVA HERZOG, Jesus. El Agrarismo Mexicano y La Reforma Agraria, México: FCE, 1959.

SOARES, Gabriela Pellegrino e COLOMBO, Sylvia. Reforma Liberal e Lutas Camponesas na América Latina: México e Peru nas últimas décadas do século XIX e Princípios do XX, São Paulo: Humanitas - FFLCH/USP, 1999.

SOARES, Gabriela Pellegrino. Projetos Políticos de Modernização e Reforma no Peru, 1950-1975. São Paulo, Humanitas - FFLCH/USP, 2001.

VILORO, Luis, El proceso ideológico de la revolución de Independencia, México, D.F.: SEP, 1986.

VON WOBESER, Gisele (coord.). História de México, México: FCE, 2010.

WOMACK JR., John, Zapata y la Revolución Mexicana, México DF: Siglo Veintiuno, 1999.

ZAPATA, Édgar Castro e GÓMEZ, Francisco Pineda. A cien años del Plan de Ayala, México: ERA, 2013. 